\title{
Blurring the Boundaries of Policy and Legislation in the Schooling of Indigenous Children in British Columbia, 1901-1951
}

\author{
Helen Raptis \\ University of Victoria
}

\section{ABSTRACT}

Historical accounts of Indigenous education maintain that until the early 1950s settler and Indigenous children were educated in separate facilities regulated under separate legislation and overseen by separate authorities. This study illustrates that in British Columbia between 1901 and 1951, the dual system of schooling seemingly embodied in government policy was not implemented by federal or provincial authorities as strictly as historians have assumed. This article illuminates the ways that officials from both systems sometimes blurred the boundaries of policies and legislation that officially circumscribed students' lives in order to enhance youngsters' access to education.

\section{RÉSUMÉ}

Des récits de l'histoire de l'éducation autochtone soutiennent que jusqu'au début des années 1950, les enfants des colons et ceux des autochtones ont été instruits dans des institutions séparées, sous des règlements et des autorités différentes. Cette étude démontre qu'entre 1901 et 1951, en Colombie-Britannique, cette dualité du système d'éducation prônée par la législation n’a pas été appliquée aussi strictement par les autorités fédérales ou provinciales que les historiens le laissent entendre. Notre étude met en lumière les façons dont certains officiels dans les deux systèmes faisaient fi des politiques et des lois encadrant officiellement la vie des élèves afin de favoriser leur accès à l'éducation.

\section{Background}

In National Dreams: Myth, Memory, and Canadian History, Daniel Francis has argued that "a nation is a group of people who share the same illusions about themselves." He refers to these illusions as "myths" — not in the sense of being untrue, but rather that they are "important images, stories, and legends" idealized from events in our history serving to link and define us as Canadians. One such myth is that of the open North American frontier where the notion of vast - allegedly unclaimed — spaces served to legitimize settlers' entitlements over lands and resources that had sustained 
Indigenous peoples' livelihoods for millenia. "Core myths" are powerful communications that serve as "master narratives" to help societal elites further their status and privilege. As Tim Stanley notes, "The problem with imagined community is that if some people are imagined as within the community, as belonging to the nation, others are imagined as being outside of it, inexorable aliens who are not and cannot be like one's self."

Another important but relatively unexplored Canadian myth stems from the contents of Section 91(24) of the 1867 British North America Act. This portion of Canada's constitution bestowed authority over Indian Affairs to the federal government. On the other hand, the Act gave provincial governments the right to govern and administer education. As a result, accounts of Indigenous education maintain that until the early 1950s settler and Indigenous children were educated in separate facilities, regulated under separate legislation and overseen by separate authorities. ${ }^{3}$ For example, F. Henry Johnson, one of Canada's earliest historians of education, states that " $[\mathrm{w}]$ hen the British North America Act was passed, making the Indians wards of the Dominion Government, and when reserves were established, the whole problem of Indian education seemed to be removed from provincial jurisdiction." 4 More recently, Young and Levin contend - albeit inaccurately — that the federal government maintained oversight of Aboriginal education but shifted "toward integrating Indian children into the provincial school systems" during the 1960s. ${ }^{5}$

Given the longstanding assumption of separate educational spheres for Indigenous and non-Indigenous children, it is understandable that historians of Indigenous education have tended to focus their inquiries almost exclusively on residential schooling. As a result, we know a good deal more about residential schools than other forms of Aboriginal schooling. ${ }^{6}$ However, the earliest educational establishments for Indigenous children were not residential schools but took the form of on-reserve day schools where children returned home to their families at the end of each school day. ${ }^{7}$ Established by religious missionaries as early as the 1700 s, these institutions pre-date residential schools by over 150 years. By Confederation in 1867, Roman Catholic, Anglican, Methodist and Presbyterian religious were all vying to convert Indigenous peoples to Christianity and had established extensive networks of day schools. These on-reserve institutions were not unlike rural schools in appearance: that is, they tended to be sparsely furnished one-room wooden structures heated with a woodburning stove. ${ }^{8}$ In addition to structural similarities, they also shared rural schools' difficulties in attracting and retaining teachers. ${ }^{9}$ Rural conditions were difficult for teachers as they contended with loneliness, isolation, less-than-ideal living quarters, few resources, and lack of connection to other teachers. ${ }^{10}$ Since Indigenous children often accompanied their families during seasonal hunting and fishing excursions, day schools also grappled with inconsistent pupil attendance. High absenteeism, in turn, prompted students to drop out often after only a few years of schooling. ${ }^{11}$

By the late 1870s, the federal Department of Indian Affairs (DIA) declared day schools to be "a very imperfect means of education."12 Prime Minister John A. MacDonald sent Nicholas Flood Davin to the United States to explore the existing Indian boarding school system. Davin was impressed with American boarding 
schools and discussed with various officials the possibility of implementing such a system in Canada. In 1879, Davin presented a report to government recommending the implementation of a boarding school system for Indigenous children throughout Canada to be sustained in collaboration with religious denominations. ${ }^{13}$ Support for boarding schools soon spread as illustrated by the comments of Edgar Dewdney, Canadian minister of the interior and former Indian commissioner. He stated that he

Never had much opinion of these day schools... [W] here those children go to school for a few hours and then return to their wigwams or houses, there is not much chance to improve them... The sooner we can close the day schools and send the children to the boarding schools, the sooner we will be able to do something with them. ${ }^{14}$

By the 1890s, Canada had inaugurated boarding schools where children aged 8 to 14 followed a general academic curriculum and industrial schools where 14 to 18 year olds trained in practical skills such as carpentry, cabinet making, and shoemaking. ${ }^{15}$ By 1909, industrial schools were considered to be financially and pedagogically inefficient, so government closed them. ${ }^{16}$ In 1923, federal authorities replaced the term "boarding" with "residential" for schools where Indigenous youngsters lodged away from their families for 10 months of the year or more until the age of $16 .{ }^{17}$

Despite their appeal in allegedly assimilating Indigenous youth into mainstream society, residential schools were expensive due to the provision of food, clothing, and shelter. Since expenses exceeded legislative funding allocations, the schools relied on the human resources of church groups as well as the students for maintenance. The "half-day system" required that students spend only half their day on academics and the rest of their day doing chores to sustain the schools. Apparently, the entire "student body was out of class for long periods at critical times such as harvest." ${ }^{18}$ Nuns taught girls domestic duties, such as cooking, doing laundry or scrubbing floors. Priests and missionaries trained boys in carpentry, as well as farming and - depending on the school — tending cattle. ${ }^{19}$ Long periods of time outside of the classroom slowed students' academic progress rendering Indigenous children less well equipped academically than their public school peers. ${ }^{20}$ This age-grade lag jeopardized students' abilities to enter high school or post-secondary institutions and consigned them to manual labour and the impulses of resource-based industries. In some cases, the children's farming skills were too rudimentary for them to compete in Canada's mainstream economic marketplace. At the same time, pupils' lack of Indigenous knowledge and skills hindered their reintegration into their home communities. ${ }^{21}$ The residential school policy was wound down in 1951, when federal legislators revised the Indian Act to legally enable Aboriginal students to be educated in provincial schools.

The legacy of the residential school system was more damaging than the students' inadequate academic and life skills would suggest. In recent years, stories have surfaced about individual students being taught that their families and cultures were inferior to their colonizers'. Educators' and officials' attitudes of cultural superiority led them to punish children physically for alleged transgressions such as speaking one's 
language. Indigenous ways of learning were rooted in communitarian "principles of respect, generosity, and a willingness to help others." ${ }^{22}$ By contrast, residential schooling was grounded in the discourse of liberalism with an emphasis on individual attainment. Thus, siblings were purposely segregated to discourage linguistic and cultural retention and to promote each child's absorption into Canadian social mores. In many cases, students suffered physical and sexual abuse at the hands of their caretakers, leading many children to hate themselves and their families, making return to their home communities difficult. It was not until 2005 that the Canadian government agreed to earmark $\$ 2$ billion in reparations to residential school survivors. In 2008, the federal government apologized to former residential school pupils for the school system's devastating impact on Aboriginal culture, heritage, and language.

From the existing scholarly literature, it would be tempting to conclude that all Indigenous children were educated in segregated residential or on-reserve day schools. Nevertheless, there is evidence, albeit limited, that the Canadian government never fully achieved its goal of wholly segregated schooling for First Nations students. As Jean Barman has noted in "Families vs. Schools: Children of Aboriginal Descent in British Columbia Classrooms of the Late Nineteenth Century," Indigenous and mixed race children were often permitted to attend British Columbia's public schools despite an official policy of segregation. For example, in 1872, at Mill Bay, just north of Victoria, school registers included the "Sheppard, Vautrain and Gabourie children [who] all had white fathers and Aboriginal mothers." ${ }^{23}$ From 1872 to 1878, John Jessop, British Columbia's first superintendent of education, submitted annual reports to government indicating that Indigenous and mixed race children attended public schools on Salt Spring Island, Gabriola Island, the Cowichan Valley on Vancouver Island, in the province's interior at Yale, Dog Creek in the Cariboo region and throughout the Okanagan Valley — to name but a few locations.

\section{Integrated Schooling in the Early $20^{\text {th }}$ Century}

Evidence from British Columbia's Annual Reports of the Public Schools (ARPS) also suggests that some Indigenous children were educated in public schools during the early decades of the $20^{\text {th }}$ century. In 1914, school inspector A.E. McGraw reported that Miss A.M. Easton, the teacher at the Okanagan Valley school, taught up to twelve Indian students whose "behaviour and aptitude to learn" were impressive. ${ }^{24}$ Nine Indian children aged ten to seventeen, whose "writing and drawing books showed marked aptitude," attended Hedley public school under the tutelage of Miss Nettie Walker. ${ }^{25}$ Two Arrow Lake Band children attended public school at Burton as well as several others in New Westminster. One Aboriginal student, Harry Harris, was enrolled in Armstrong High School's matriculation class and was expected to succeed at his exam that summer. The following year, Indian Agent J.R. Brown confirmed these students' continued good progress and also noted that Miss K. Lawrence of Larkin School taught two promising Indian students while Miss Minnie Smith of Wood Lake School reported her five Indian students to be achieving well. ${ }^{26}$ Further north in the coastal town of Port Essington, Edward Bolton, was the "first native 
scholar in BC to have been successful in passing his [high school] entrance examination from an Indian Reserve day school," and had enrolled in King Edward High School in Prince Rupert in $1935 .^{27}$

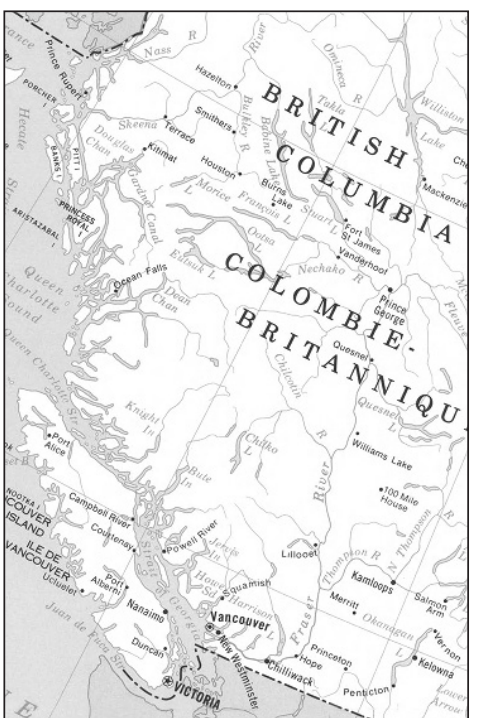

Figure 1: Map of British Columbia
The ability of Indigenous pupils to attend provincial schools was largely dependent upon financial support from the federal government. In 1915, Indian Affairs paid British Columbia $\$ 165.34$ in total tuition fees for educating onreserve status Indian students in off-reserve public schools. Legislation made schooling mandatory for Indigenous children in 1920, leading to increased enrolment, accompanied by an almost five-fold increase in federal tuition fees to $\$ 738.40$ by $1925 . .^{28}$ British Columbia was not the lone recipient of federal funding for educating Indigenous children in public schools. Indian Affairs Annual Reports reveal that throughout the first half of the $20^{\text {th }}$ century Canada financed the public schooling of Indigenous children across the country. In 1915, the province of Quebec received the most federal funding for tuition fees at $\$ 6,717.80$. The second highest amount-at $\$ 1,362.57$ — went to Ontario, indicating that Quebec educated far more Indigenous children in public schools than any other of Canada's provinces. ${ }^{29}$

It is important to note, however, that upon securing federal funding Indigenous students were not automatically granted the right to attend public schools during the first half of the $20^{\text {th }}$ century. Their integration was dependent on various local factors as well, not the least of which were the ever-changing sentiments of settler families, as illustrated by the following case from the Saanich peninsula, northeast of the city of Victoria. In 1915, the Tsartlip Indian Day School closed due to low pupil enrolment. It appears that many of the pupils from the Tsartlip reserve were in fact attending West Saanich School, established and funded by the province. However, in 1928 trustees voted to bar the Indigenous children from the school. Some trustees complained that over one quarter of the school's students had failed their summer exams and they attributed this poor showing to "unduly large classes, forty children being instructed by one teacher." ${ }^{30}$ One board member, Chairman Hobbs, opposed the motion, arguing that "exclusion would be followed by emigration of many excellent Indian families to the United States, where their children [would] be given education." ${ }^{31}$ Hobbs noted that since the federal government paid the children's tuition fees, these funds could be used to add an additional classroom to the public school, thus accommodating the increased population. The pro-exclusion trustees won the day however, bolstered by the attitudes of settler parents who feared that Indigenous 
children carried diseases - fears that were declared to be "groundless" by Doctors Berman and Whitehead. ${ }^{32}$

One of the more curious examples of Indigenous children being schooled alongside settler children comes from Telegraph Creek in the far north of British Columbia. The land in and around Telegraph Creek constitutes the traditional territory of the Tahltan people whose population had declined from 1,500 in the 1830 s to approximately 325 during the late 1840 s due to their lack of immunity to settler carried illnesses. When gold was discovered in the late 1870s in the Cassiar and Klondike areas in the northernmost points of the province, miners and capitalists flooded to the region. Following on their heels were Protestant and Catholic missionaries, who established churches and schools for the salvation of both settler and Indian souls. ${ }^{33}$

When Dr. Inglis, a Presbyterian medical missionary, arrived in Telegraph Creek in 1905 , he was troubled by the absence of a church, school, or hospital. ${ }^{34}$ With 25-30 settlers and approximately 150 Tahltan living in and around the settlement, Dr. Inglis believed there was a need for religious and educational guidance. ${ }^{35} \mathrm{He}$ and his wife moved quickly to set up a large floored tent where they conducted two services on Sundays: one in the afternoon for English settlers and one in the morning for the Tahltan, facilitated by a Native interpreter." ${ }^{36}$ Inglis and his wife also conducted school during the week and invited children of all denominations to attend.

By 1906, the couple had secured provincial funding to convert a former saloon to a church and an outfitter's store into Telegraph Creek public school. They also appointed three trustees who encouraged local Tahltan children to attend with the few settler pupils in order to meet the province's minimum requirement of ten children to maintain a school. In 1912, a new log schoolhouse was built using funds from provincial education officials who also supplied textbooks free of charge. ${ }^{37}$

From 1912 until the late 1940s, Telegraph Creek Elementary functioned as an "un-officially" integrated school with funding and administrative oversight shared by both provincial and federal authorities. ${ }^{38}$ Ironically, the federal government's post-World War II initiative to officially wind down separate school facilities for Indigenous children unintentionally resulted in segregating Indigenous from nonIndigenous pupils at Telegraph Creek.

In 1948, the final report of the federal Special Joint Committee of the Senate and House of Commons tasked with investigating Indian Affairs had recommended extensive changes to Canada's Indian Act. With respect to education, the Committee recommended that Indian children be educated "in association with other children." 39 Accepting the recommendations, the federal government amended the Indian Act in 1951 enabling the Minister of Indian Affairs to enter into agreements with provincial governments, territorial councils, school boards or religious or charitable organizations for the schooling of Aboriginal children living on reserve. ${ }^{40}$ Canada supported this legislation with lucrative financial incentives to help with the integration of Indigenous children into provincial schools and the renovation of existing facilities or construction of new ones where necessary.

Few scholars have investigated Canada's post-war shift from a policy of segregated to integrated schooling for Indigenous children. In Shingwauk's Vision, James Miller's 
seminal work on Canada's residential schools, he attributes national economic issues as the impetus for government's policy shift to integrated education. ${ }^{41}$ That is, integration provided a more cost-effective way to educate a growing Native population than attempting to renovate and expand existing segregated schools that were in various stages of disrepair due to federal budget cuts implemented during the Depression and World War II. Historian John Milloy supports Miller's view, citing a twofold rationale for Canada's shift from segregated to integrated schooling: policymakers' longstanding goal to assimilate Native peoples into Canadian society and "mundane financial considerations." ${ }^{42}$

In November 1949, a new threeroom school was opened in Telegraph Creek, jointly funded by federal and provincial governments. It was officially designated as "integrated by the Telegraph Creek School district and the federal Minister of Citizenship and Immigration" after roughly 40 years of "unofficial" integration. ${ }^{43}$ However, due to lobbying by church officials, Catholic Indigenous children would no longer attend school alongside their non-Indigenous peers. Instead,

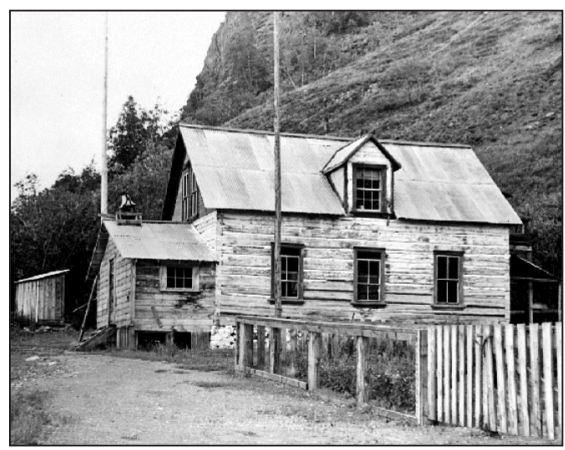

Figure 2: Telegraph Creek public school, 1952. Courtesy BC Archives I-31887 Catholic Indigenous children who once attended Telegraph Creek School found themselves segregated into a newly-constructed residential school at Lower Post just south of the Yukon border. Ironically, the federal shift to integrated schooling had the unintended consequence of segregating — along religious lines — previously integrated pupils from both settler and Indigenous families. ${ }^{44}$

\section{Making it Work: Federal-Provincial Authorities}

The narrative of separate educational spheres for Indigenous and non-Indigenous learners also belies evidence that economic hardship during both the Depression and World War II had forced the Canadian Department of Indian Affairs to collaborate with provincial authorities to sustain school inspection. In an attempt to cut costs due to falling government revenues, the federal government reduced their complement of school inspectors. BC's inspectors lent a hand by inspecting federal day schools in regions with insufficient federal manpower. ${ }^{45}$ This was the case in 1942 , when provincial inspector Bergie Thorsteinsson replaced federal inspector Gerald Barry in the Prince Rupert region of the province. The change from federal to provincial inspectors was welcomed by one teacher in particular, Mrs. Elizabeth Pogson, who had begun teaching in 1930 at Port Essington Indian Day School on the south bank of the Skeena River, southeast of Prince Rupert. ${ }^{46}$

Pogson's work at Port Essington Indian Day School initially proceeded smoothly, 
with her students making satisfactory progress. She possessed a second-class teaching certificate and came highly recommended after eight successful years in Manitoba's public schools. Nevertheless, in 1936 Pogson's situation worsened when Indian Affairs Inspector Gerald H. Barry began filing unfavorable teaching reports with Indian Affairs officials. Inspector Barry noted that the children - particularly the first graders - were making poor progress. This he attributed to "too many children for this rather elderly [46-year-old] teacher....." 47 Barry also arranged for the ten mixed heritage students plus Pogson's own daughter to be transferred out of the day school to the local public school.

Inspector Barry's assessment of Pogson's teaching may have been more ideological than substantive and certainly did not reflect the glowing reference she had received from School Inspector Hartely after many years of service in Manitoba. Barry lamented that Pogson was "rather too old to make much use of 'Demonstration and Type Lessons.' Her knowledge of the Psychology of Teaching is ... very limited, hence she does not get the best results. "48 As elsewhere in North America, by the mid-1920s, educational psychology had become well entrenched in normal school curricula, covering various topics such as "General Modes of Human Behaviour." 49 Having received her teaching certificate in the early 1900s, Pogson may have used more "traditional" methods of which "modern" educationists, such as Barry, disapproved. When provincial inspector Bergie Thorsteinsson replaced Barry in 1942, he was much more tolerant of Pogson's techniques which he characterized as "not the most modern" but "effective." 50 Despite endorsing Pogson's work, Thorsteinsson made no attempt to return Pogson's daughter or the children of mixed heritage to the day school.

Nevertheless, the segregation of Indigenous and non-Indigenous children at Port Essington could not hold for much longer. In November 1944, Inspector Thorsteinsson reported that Mrs. Pogson was "carrying on in her usually conscientious and efficient manner" and that primary level children were particularly good at reading. However, of the 19 students enrolled, 12 were making fair or bad progress, largely due to poor daily attendance. ${ }^{51}$ Absenteeism frustrated government and church officials alike who blamed parents for taking their children with them during fishing and logging excursions. ${ }^{52}$ On May 30, 1947, Pogson's ill health prompted her to submit her resignation to the federal Indian Agent. In September of that year, she led the day school pupils over to Port Essington Elementary School where she left them in the hands of the public school teacher: Miss Esther Olynyk.

\section{Conclusion}

As these few examples make clear, neither provincial nor federal authorities adhered strictly to separate schooling for Indigenous and settler children as per legislation laid out in the Canadian constitution. These glimpses also indicate that throughout BC some Indigenous children were schooled alongside other settler children prior to the passage of legislation that legalized such practices in 1951. Annual tuition transfers documented in Department of Indian Affairs Annual Reports further verify that 
British Columbia was not the only province to integrate Indigenous children into provincial schools prior to 1951 legislation that would enable such practices. In some cases, such as Telegraph Creek, it is clear that Indigenous pupils were educated with non-Indigenous children right from the establishment of the school with costs borne equally by provincial and federal authorities.

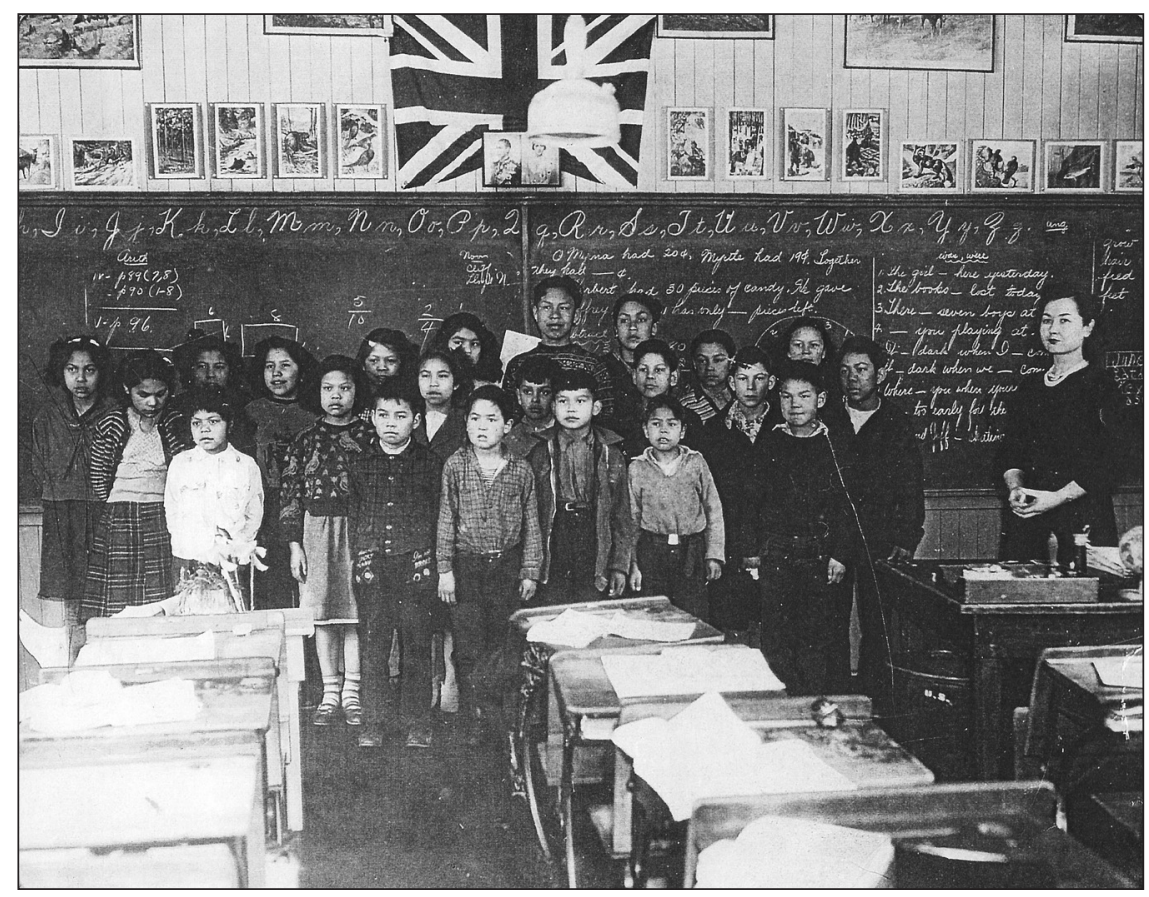

Figure 3: Port Essington Elementary School, Class of 1947-1948. Miss Olynyk is on the far right. Photo courtesy of Cynthia Bohn, Kitsumkalum Band Council

The stories told in this paper also reveal something about the character of the civil servants who administered both federal and provincial school systems. It has been argued that the officials who managed education in British Columbia and elsewhere in North America until the mid-20 $0^{\text {th }}$ century consisted predominantly of small "l" liberals motivated by progressive ideas about the value of social and educational change. ${ }^{53}$ In short, they sometimes blurred the boundaries of policies and legislation that officially circumscribed students' lives in order to enhance youngsters' access to educational opportunities.

Finally, Adele Perry has noted that following World War II, English Canadian historians shifted their gaze from the dominant analytic frame of the "empire" to that of the "nation" - to which we remain somewhat wedded today. The predominance of the nation as an analytic frame may help to explain why historians have tended to restrict their research focus to federal residential schooling while neglecting other — more local — forms of Indigenous education. Master narratives — such as 
the myth of separate school spheres for Indigenous and settler children - have served to define us as Canadians. Yet, as Daniel Francis and others have noted, master narratives have recently lost their explanatory power since all myths can only be partial renderings of history seen through specific narrow lenses. ${ }^{54}$ Recently, some researchers, such as Adele Perry and Katie Pickles have gently prodded Canadian historians in more global directions. Others, such as Steven High, have maintained the importance of shifting to smaller analytic units, such as regional or local communities. Hopefully, movement in either direction - more locally toward the community or more broadly beyond the nation state - will help historians to craft a more fulsome portrayal of Indigenous education that encompasses not only residential schools, but public schools, on-reserve day schools, and other forms of education that may not have occurred in schools at all.

\section{Notes}

I wish to acknowledge the helpful feedback of Sean Carleton, Bob Gidney, and two anonymous HSE reviewers.

1 Daniel Francis, National Dreams: Myths, Memory, and Canadian History (Vancouver, BC: Arsenal Pulp Press, 1997), 10.

2 Tim Stanley, "Whose Public? Whose Memory? Racism, Grand Narratives and Canadian History" in To the Past: History Education, Public Memory, and Citizenship in Canada ed. Ruth Sandwell (Toronto, ON: University of Toronto Press, 2006), 33.

3 F. Henry Johnson, A History of Public Education in British Columbia (Vancouver, BC: UBC Press, 1964), 135; see also Charles Phillips, The Development of Education in Canada (Toronto, ON: W.J. Gage \& Co., 1957), 336.

4 Johnson, A History of Public Education, 135.

5 Jon Young and Benjamin Levin, Understanding Canadian Schools: An Introduction to Educational Administration, $2^{\text {nd }}$, ed (Toronto, ON: Harcourt, Brace and Company, Canada, 1998), 47. In fact, the federal government's move toward integration policy began during the late 1940s and became official policy in 1951 with revisions to the Indian Act. See Helen Raptis, "Implementing Integrated Education Policy for OnReserve Aboriginal Children in British Columbia, 1951-1981," Historical Studies in Education 20 (2008): 120.

6 According to Jean Barman, the "residential school has become a metaphor for the history of Aboriginal education in British Columbia, as in Canada more generally." See "Schooled for Inequality: The Education Of British Columbia Aboriginal Children," in Children, Teachers and Schools In The History of British Columbia, ed. Jean Barman, Neil Sutherland and J. Donald Wilson (Calgary, AB: Detselig, 1995), 57.

7 Hope MacLean, "A Positive Experiment in Aboriginal Education: The Methodist Ojibwa Day Schools in Upper Canada, 1824-1833," The Canadian Journal of Native Studies XXII 1 (2002): 23-63.

8 Thomas G. Andrews, "Turning the Tables on Assimilation: Oglala Lakotas and the Pine Ridge Day Schools, 1889-1920s," Western Historical Quarterly 33 (Winter 2002): 1-20; Edwin Dexter, History of Education in the United States (New York: Burt Franklin, 1906); Thomas Fleming, Lisa Smith, and Helen Raptis, "An Accidental Teacher: Anthony Walsh and the Aboriginal Day Schools at Six Mile Creek and Inkameep, British Columbia, 1929-1942," Historical Studies in Education 19 (Spring 2007): 1-24 and Noel Dyck, What is the Indian 'Problem': Tutelage and Resistance in Canadian Indian Administration (St. John's: Institute of Social and Economic Research, 1991), 50. 
9 Ken Coates, "A Very Imperfect Means of Education: Indian Day Schools in the Yukon Territory," in Indian Education in Canada, Volume 1: The Legacy, ed. Jean Barman, Yvonne Hébert, and Don McCaskill (Vancouver, BC: UBC Press, 1986), 138-140; Brian Titley, A Narrow Vision: Duncan Campbell Scott and the Administration of Indian Affairs in Canada (Vancouver, BC: UBC Press, 1986), 89.

10 For rural BC experiences, see Alastair Glegg, "Anatomy of a Tragedy: The Assisted Schools of British Columbia and the Death of Mabel Jones," Historical Studies in Education 17 (Spring 2005): 145-64; Robert S. Patterson, "Voices From the Past: The Personal and Professional Struggle of Rural School Teachers," in Schools in the West: Essays in Canadian Educational History, ed. Nancy Sheehan, J. Donald Wilson and David C. Jones (Calgary: Detselig, 1986), 99-111; Paul J. Stortz and J. Donald Wilson, "Education on the Frontier: Schools, Teachers and Community Influence in NorthCentral British Columbia," Histoire Sociale — Social History XXVI (November 1993): 265-290; J. Donald Wilson and Paul Stortz, "May the Lord Have Mercy on You: The Rural School Problem in British Columbia in the 1920s," BC Studies 79 (Autumn 1988): 24-57.

11 W.D. Hamilton, The Federal Indian Day Schools of the Maritimes (Fredericton, NB: University of New Brunswick, 1986), 14.

12 Coates "A Very Imperfect Means of Education"; E. Brian Titley, "Duncan Campbell Scott and Indian Educational Policy" in An Imperfect Past: Education and Society in Canadian History, ed. J. Donald Wilson (Vancouver, BC: Canadian History in Education Association, 1984), 143. See also John Leslie, "The Bagot Commission: Developing Corporate Memory for the Indian Department," in Historical Papers of the Canadian Historical Association, presented in Ottawa, 1982, 40; Reverend Thompson Ferrier, Our Indians and Their Training for Citizenship (Toronto: ON: Young People's Forward Movement, n.d.).

13 Brian Rice and Anna Snyder, "Reconciliation in the Context of a Settler Society: Healing the Legacy of Colonialism in Canada" in From Truth to Reconciliation: Transforming the Legacy of Residential Schools, ed. Marlene Brant Castellano, Linda Archibald, and Mike DeGagné (Ottawa, ON: Aboriginal Healing Foundation, 2008), 52.

14 James [sákéj] Youngblood Henderson, "Treaties and Indian Education," in First Nations Education in Canada: The Circle Unfolds, ed. Marie Battiste and Jean Barman (Vancouver: University of British Columbia Press, 1995), 252-3.

15 D.J. Hall, Clifford Sifton, Volume 1: The Young Napolean, 1861-1900 (Vancouver, BC: UBC Press, 1981), 270; Titley, A Narrow Vision, 77.

16 Titley, A Narrow Vision, 83; Titley, "Duncan Campbell Scott," 145. See also J.R. Miller, Shingwauk's Vision: A Hisory of Native Residential Schools (Toronto, ON: University of Toronto Press, 1996), 103.

17 Titley, "Duncan Campbell Scott," 147.

18 Miller, Shingwauk's Vision, 418-19.

19 E. Brian Titley, "Red Deer Indian Industrial School: A Case Study in History of Native Education," in Exploring our Educational Past, ed. Nick Kach and Kas Mazurek (Calgary, AB: Detselig, 1992), 57.

20 Barman, "Schooled for Inequality," 63.

21 Agnes Grant, No End of Grief: Indian Residential Schools in Canada (Winnipeg, MB: Pemmican Publications Inc., 1996), 247.

22 Ibid., 35.

23 Jean Barman, "Families vs. Schools: Children of Aboriginal Descent in British Columbia Classrooms of the Late Nineteenth Century," in Family Matters: Papers in Post-Confederation Canadian Family History ed. Edward Montigny and Lori Chambers (Toronto, ON: Canadian Scholars Press), 77. 
24 Raptis, "Implementing Integrated Education Policy for On-Reserve Aboriginal Children," 120.

25 Ibid. Hedley is also in BC's Okanagan region.

26 Ibid.

27 Phylis Bowman, Klondike of the Skeena (Chilliwack, BC: Sunrise Printing, 1982), 65.

28 Dominion of Canada, Department of Indian Affairs (DIA) Annual Reports for the Year Ended $31^{\text {st }}$ December, 1915, 123.

29 This is likely due to the large number of Indigenous families who converted to Catholicism and whose children would have been educated in Quebec's Catholic public system.

30 "Indians Must Quit School — Saanich Excludes Native Children From West Saanich School," Times, November 15, 1928, 5.

31 Ibid.

32 Ibid.

33 Eve Chapple and Helen Raptis, "From Integration to Segregation: Government Education Policy and the School at Telegraph Creek, British Columbia, 1906-1951," Journal of the Canadian Historical Association 24(1): 136.

34 Ibid.

35 Ibid.

36 Ibid., 138.

37 Ibid., 139.

38 Ibid., 152.

39 Department of Mines and Resources, Indian Affairs Branch, Education Service Annual Report, 1949, 199.

40 Indian Act, 1951, section 113 (b).

41 Miller, Shingwauk's Vision, 382.

42 John Milloy, A National Crime: The Canadian Government and the Residential School System, 1879 to 1986 (Winnipeg, MB: University of Manitoba Press, 1999), 192.

43 Chapple and Raptis, "From Integration to Segregation," 153.

44 Ibid.

45 British Columbia Archives (BCA), GR-1071, box 1, file 8. Indian Advisory Committee, Annual Report 1951; see also Harry B. Hawthorn, Cyril S. Belshaw, and Stuart M.

Jamieson, The Indians of British Columbia (Berkley, CA: University of California Press, 1960), 291.

46 Library and Archives Canada (LAC), RG-10 Indian Affairs, volume 6407, file 8, 13 December 1943.

47 LAC RG-10, Indian Affairs volume 6407, file 836-1, Inspector's Report on Port Essington Indian Day School, 1 May 1936 and 14 May 1936.

48 Ibid. A.F. MacKenzie to W.E. Collison, 29 May 1936 and 19 June 1936; W.E. Collison to A.F. MacKenzie, 11 June 1936.

49 Regulations and Courses of Study for Provincial Normal Schools, 1928-1929, available at www.mala.bc.ca/homeroom/content/topics/programs/Curriclm/nschool.htm [accessed 25 January 2008]; See also Robert Patterson, "Society and Education During the Wars and Their Interlude, 1914-1945," in Canadian Education: A History, ed. J. Donald Wilson, Robert Stamp and Louis-Philippe Audet (Scarborough, ON: PrenticeHall, 1970), 360-384 Neil Sutherland, Children in English Canadian Society: Framing the Twentieth Century Consensus (Toronto: University of Toronto Press, 1976), 182201; George Tomkins, A Common Countenance: Stability and Change in the Canadian Curriculum (Scarborough, ON: Prentice-Hall, 1986), 242-47.

50 LAC, RG-10 Indian Affairs, volume 6407, file 8, 13 December 1943.

51 LAC, RG-10 Indian Affairs, volume 6407, file 8, Inspector's Report on Port Essington Indian Day School, 3 November 1944; Port Essington Indian Day School, Quarterly Return, March 1944. 
52 LAC, RG-10 Indian Affairs, volume 6407, file 8, J. Gillett to Major D.M. MacKay, 23 January 1945; BSA, Prince Rupert Presbytery: Minutes, 23 August 1944, 60.

53 Helen Raptis, "A Tale of Two Women: Edith Lucas, Mary Ashworth, and the Changing Nature of Educational Policy in British Columbia, 1937-1977," Historical Studies in Education 17 (2005): 318; Thomas Fleming, "From Educational Government to the Government of Education: The Decline and Fall of the British Columbia Ministry of Education, 1972-1996," Historical Studies in Education 15 (Fall 2003): 210-36. See also Bruce Fuller, "Education Policy Under Cultural Pluralism," Educational Researcher 32 (2003): 19.

54 Francis, National Dreams, 12; Stanley, "Whose Public? Whose Memory?" 33. 